\title{
KONVERGENSI PERTUMBUHAN EKONOMI DI NUSA TENGGARA BARAT PERIODE TAHUN 2010 - 2015
}

\author{
Wahyunadi \\ Fakultas Ekonomi dan Bisnis, Universitas Mataram \\ email korespondensi: nadi_zaz@yahoo.com
}

\begin{tabular}{|c|c|}
\hline & ABSTRAK \\
\hline $\begin{array}{l}\text { Kata Kunci: } \\
\text { pertumbuhan ekonomi, } \\
\text { convergence }\end{array}$ & $\begin{array}{l}\text { Penelitian ini bertujuan untuk menganalisis arah } \\
\text { percepatan pertumbuhan ekonomi daerah melalui } \\
\text { pengujian hipotesis konvergensi di provinsi Nusa } \\
\text { Tenggara Barat. } \\
\text { Metode analisis data yang digunakan dalam penelitian ini } \\
\text { adalah menggunakan Analisys Convergence Model Barro- } \\
\text { Sala-i- Martin (2004) dengan menggunakan regresi data } \\
\text { panel melalui pendekatan CEM dan FEM. } \\
\text { Hasil penelitian ini menunjukkan terjadi tendensi } \\
\text { konvergensi absolut pendapatan perkapita antar } \\
\text { Kabupaten/Kota di Provinsi NTB selama periode 2010- } \\
\text { 2015. Hal ini ditunjukkan oleh nilai koefisien parameter } \\
\text { pendapatan per kapita awal ( } \beta \text { ) yang memiliki arah (sign) } \\
\text { negatip, sesuai harapan atau konsisten dengan teori dan } \\
\text { dengan kecepatan konvergensi absolut berkisar antara } 2,14 \\
\% \text { hingga 3,710\% per tahun serta half-life antara selama } 19 \\
\text { - 32 tahun. Pendugaan proses conditional convergence } \\
\text { menunjukkan kecepatan yang berbeda-beda, masing- } \\
\text { masing sebesar 0,98\% per tahun, 3,63\% per tahun dan } \\
\text { bermuara pada perbedaan percepatan pencapaian half-life, } \\
\text { masing-masing selama } 28 \text { tahun, dan } 19 \text { tahun. }\end{array}$ \\
\hline
\end{tabular}




\section{LATAR BELAKANG}

$$
\text { Berbagai teori tentang }
$$
pertumbuhan ekonomi telah berusaha mengisolasi beberapa faktor yang diduga mempengaruhi proses pertumbuhan. Akumulasi stok kapital diyakini sebagai salah satu faktor penting dalam proses pertumbuhan ekonomi disamping faktorfaktor lain seperti tenaga kerja, ketersediaan sumberdaya alam dan kemajuan teknologi. Demikian pula halnya dengan kualitas sumber daya manusia dan peranan pemerintah dalam perekonomian akan turut menjadi faktor penentu pertumbuhan ekonomi. Peranan pemerintah dalam perekonomian tercermin dari serangkaian kebijakan baik melalui kebijakan fiskal dan moneter.

Romer (1986), Lucas (1988), Barro (1990), Barro, sala-i-Martin (1989) dan Rabelo (1991) mengembangkan model pertumbuhan endogenous dimana pemerintah memegang peranan penting dalam proses pertumbuhan ekonomi. Broons, de Groot dan Nijkamp (1999) menyatakan bahwa sektor pemerintah dapat berpengaruh secara langsung ataupun tidak langsung terhadap pertumbuhan. Sementara Dar dan Amir Khalkahli (2002) memberikan kesimpulan bahwa kebijakan pemerintah dapat mempengaruhi pertumbuhan dalam jangka panjang melalui tiga instrumen fiskal yaitu : pajak, pengeluaran pemerintah dan keseimbangan anggaran. Ketiga komponen tersebut berpengaruh pada tingkat efisiensi penggunaan sumberdaya (efficiency of resource use), akumulasi faktor produksi (production factor accumulation) dan perkembangan teknologi (technological progress).

Salah satu kebijakan pemerintah yang erat kaitannya dengan upaya mobilisasi faktor produksi adalah melalui kebijaksanaan fiskal. Dalam manajemen

ekonomi

modern

kebijaksanaan fiskal mengandung tiga tujuan utama yaitu; Pertama adalah mempengaruhi alokasi sumber-sumber ekonomi (resource allocation). Tujuan kebijaksanaan fiskal dalam konteks ini adalah untuk menemukan keseimbangan yang tepat baik dalam bentuk riil maupun nominal diantara alokasi sumber-sumber ekonomi untuk sektor publik dan opportunity cost pengalihan sumbersumber ekonomi dari pengusaha pihak swasta. Kedua, adalah untuk melakukan proses redistribusi kekayaan dan pendapatan antar golongan ekonomi masyarakat. Dalam hal ini kebijaksanaan fiskal bertujuan untuk memperoleh keseimbangan antar individu (interpersonal balance) dalam pendapatan bersih atau kesejahteraan. Ketiga, adalah untuk menentukan arah pertumbuhan dan kestabilan ekonomi nasional. Oleh karena itu kebijaksanaan fiskal harus mampu merekayasa tindakan-tindakan yang akan melancarkan pemanfaatan secara optimal sumberdaya-sumberdaya seperti sumberdaya alam, sumberdaya manusia dan sumber keuangan.

Kebijaksanaan sektoral dan regional berkaitan dengan penentuan arah dan besarnya investasi pemerintah untuk mempengaruhi laju pertumbuhan ekonomi di daerah. Peranan pemerintah menjadi sangat penting untuk menjamin tercapainya penggunaan sumber-sumber ekonomi yang efisien dalam rangka memacu pertumbuhan ekonomi di daerah. Berdasarkan uraian pada latar belakang dan identifikasi masalah di atas, maka dalam penelitian ini dibuat rumusan masalah sebagai berikut : Bagaimana arah percepatan pertumbuhan ekonomi daerah kabupaten/kota di Nusa Tenggara Barat. Penelitian sesungguhnya ini akan menguji eksistensi hipoteisis konvergensi dari teori ekonomi Neo-Kalsik (Solow-Swan) yang menyatakan bahwa negara/daerah 
terbelakang/miskin pada suatu waktu akan dapat melampui pertumbuhan ekonomi negara/daerah maju. Hipotesis konvergensi ini sampai saat ini masih menjadi topik perdebatan yang menarik, oleh karena itu penelitian ini akan membuktikan apakah terjadi tendensi konvergensi antar daerah kabupaten/kota dalam proses pembangunan di provinsi Nusa Tenggara Barat?

\section{TINJAUAN PUSTAKA}

\section{Pertumbuhan Ekonomi}

Pertumbuhan ekonomi diartikan sebagai peningkatan pendapatan domestik bruto (PDB) yaitu keseluruhan nilai produksi barang dan jasa yang dihasilkan suatu perekonomian dalam periode tertentu. Perhitungan nilai barang dan jasa (PDB) dapat dilakukan dari sisi permintaan (demand side) dan sisi penawaran (supply side). Pertumbuhan ekonomi melalui sisi permintaan dipicu oleh peningkatan konsumsi masyarakat sementara pertumbuhan ekonomi melalui sisi penawaran diakibatkan oleh peningkatan produktivitas faktor-faktor produksi seperti tenaga kerja, kapital, perubahan tekhnologi dan peningkatan kualitas sumber daya manusia.

Berbagai literatur dan model empiris yang dapat dijadikan sebagai landasan dalam menganalisis pengaruh variabel ekonomi dan non ekonomi terhadap pertumbuhan. Model pertumbuhan dinyatakan dalan bentuk hubungan fungsional antara variabel dependen dan sejumlah variabel penjelas (explanatory varible). Model pertumbuhan Neo-klasik mendasarkan analisisnya pada model fungsi produksi Cobb-Douglas : (Mankiw, 2000), (Barro, Sala-i-Martin, 1995) :

$$
Y_{t}=A_{t} \cdot K_{t}^{\alpha} L_{t}^{\beta}
$$

$Y t$ : tingkat pertumbuhan pada tahun $t$.
At : tingkat kemajuan teknologi pada tahun $t$.

Kt : jumlah stok modal pada tahun $t$.

Lt : jumlah tenaga kerja pada tahun $t$.

$\alpha, \beta$ : elastisitas produksi dari input modal dan tenaga kerja.

Mankiw, (2000: 73-75), Barro, Salai-Martin, (1995: 70), Barro,(2004), Romer (2001) menyatakan bahwa model pertumbuhan neo-klasik mengasumsikan bahwa fungsi produksi memiliki pengembalian skala konstan (constan returns to scale), berlakunya hasil yang semakin menurun pada setiap input (diminishing returns) dan elastisitas positif penggantian antara setiap input. Model struktur dasar fungsi produksi pertumbuhan ekonomi Solow adalah sebagai berikut :

$$
Y=F(K, L)
$$

Kondisi constan returns to scale (pengembalian skala konstan) terhadap output dapat diformulasikan sebagai berikut :

$Y=F(K, L)=L \cdot F(K / L, 1)=L \cdot f(k)$

$k=K / L$ adalah ratio modal pertenaga kerja.

$y=Y / L$ adalah menunjukkan jumlah output perpekerja.

Selanjutnya dinyatakan bahwa persediaan kapital merupakan determinan tingkat output suatu perekonomian yang dapat berubah sepanjang waktu dan berimplikasi terhadap tingkat pertumbuhan ekonomi. Dua kekuatan yang saling berpengaruh terhadap persediaan kapital yaitu investasi $(i)$ dan penyusutan $(\delta)$. Investasi mengacu pada penambahan peralatan baru sehingga persediaan modal bertambah, sementara penyusutan $(\delta)$ mengacu pada penggunaan kapital sehingga menyebabkan persediaan kapital menurun. Investasi per pekerja sebagai fungsi dari persediaan kapital per pekerja dinyatakan sebagai berikut :

$$
\begin{gathered}
i=s f(k) . \\
\Delta k=i-\delta k
\end{gathered}
$$


Semakin tinggi jumlah persediaan kapital, maka semakin besar output y, dan investasi $i$, tetapi sebaliknya jumlah penyusutan menjadi semakin besar. Proses ini akan berlangsung terus sampai tingkat penyusutan ( $\delta$ ) sama dengan investasi (i). Jika perekonomian berada pada tingkat persediaan kapital tunggal $\mathrm{k}^{*}$ ( investasi dan penyusutan seimbang) dimana $\Delta \mathrm{k}=0$, maka perekonomian berada pada kondisi mapan $\mathrm{k}^{*}$ ( steady state level of capital). Perekonomian yang tidak berada dalam keseimbangan akan cenderung menuju kepada kondisi mapan (steady state level) yang menunjukkan keseimbangan perekonomian jangka panjang.

Model pertumbuhan Neo-klasik jika dilihat dari sudut pandang ekonomi regional adalah bahwa terdapat hubungan antara tingkat pertumbuhan suatu negara dengan perbedaan kemakmuran daerah pada negara tersebut. Pada saat proses awal pembangunan tingkat perbedaan kemakmuran antar wilayah cenderung meningkat (divergence), dan setelah proses pembangunan berjalan lama (jangka panjang) maka perbedaan kemakmuran antar daerah cenderung menurun (convergence). Alasan yang diajukan adalah pada negara yang sedang berkembang lalu lintas faktor produksi (tenaga kerja, kapital) tidak lancar sehingga proses penyesuaian ke arah tingkat pertumbuhan antar daerah tidak terjadi. Sementara pada negara-negara maju proses penyesuaian dapat berjalan dengan lancar karena sudah tersedia fasilitas infrastruktur yang memadai.

Dixon dan Thirwal (1974) dalam Ray (1995) menjelaskan mengenai perbedaan kemakmuran antara daerah yang cenderung menurun (convergence) adalah berbeda dengan Neo-klasik. Daerah yang maju akan tetap berkembang secara pesat karena adanya hubungan positif antara kemajuan teknologi dengan tingkat keuntungan perusahaan.
Sedangkan daerah yang kurang berkembang akan tetap tumbuh secara lambat karena tingkat keuntungan yang diperoleh pengusaha masih rendah. Dengan demikian peningkatan pemerataan hasil pembangunan antar daerah tidak dapat diserahkan sepenuhnya kepada mekanisme pasar seperti yang dikemukakan neo-klasik. Dalam hal ini, maka campur tangan pemerintah melalui kebijakan-kebijakan pembangunan daerah terutama diarahkan ke daerah yang relatif masih terbelakang sangat diperlukan. Implikasi yang paling menarik dari model Solow-Swan adalah eksistensi dinamika transisional dari model tersebut. Dinamika transisional menunjukkan bagaimana pendapatan perkapita suatu perekonomian akan konvergens menuju posisi steady state levelnya dan posisi pendapatan perkapita perekonomian yang lain.

Gambar : 2. 1. Transisi Dinamis Model Solow-Swan

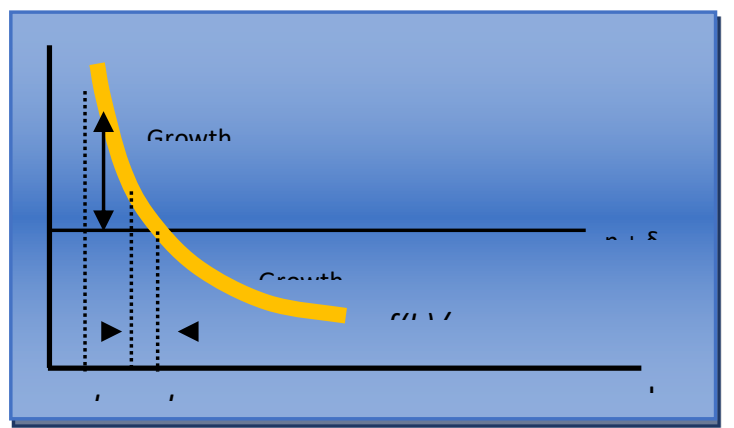

Sumber : Barro, Sala-i-Martin, (1995,2004).

Kurva $\mathrm{s} \bullet \mathrm{f}(\mathrm{k}) / \mathrm{k}$ berada di atas garis $\mathrm{n}+\delta$ - Maka tingkat pertumbuhan akan positif dan $\mathrm{k}$ meningkat sepanjang waktu (t). Bersamaan dengan naiknya $\mathrm{k}, \gamma_{\mathrm{k}}$ menurun dan mendekati 0 . sementara $\mathrm{k}$ semakin mendekati $k^{*}$. Hasil tersebut menunjukkan asumsi diminishing returns to capital, yaitu ketika rasio kapital per tenaga kerja $\mathrm{k}$ rendah rata-rata tingkat hasil $\mathrm{f}(\mathrm{k}$ )/k relatif tinggi. Dengan berasumsi bahwa tingkat tabungan dan investasi s adalah 
tetap maka ketika $\mathrm{k}$ rendah maka rasio investasi kotor pertenaga kerja $s \bullet \mathrm{f}(\mathrm{k}) / \mathrm{k}$ relatif tinggi. Dan kapital pertenaga kerja $\mathrm{k}$ akan terdepresiasi pada tingkat konstan $n$ $+\delta$. Akibatnya tingkat pertumbuhan $\gamma_{\mathrm{k}}$ juga relatif tinggi. Tingkat pertumbuhan ditunjukkan oleh garis vertikal antara kurva tabungan $\mathrm{s} \bullet \mathrm{f}(\mathrm{k}) / \mathrm{k}$ dan garis depresiasi efektif $\mathrm{n}+\delta$.Jika k $>\mathrm{k}^{*}$ maka $\gamma$ $\mathrm{k}$ positif dan $\mathrm{k}$ akan meningkat mendekati

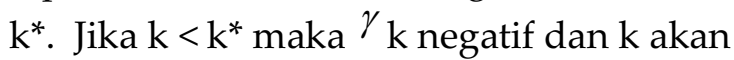
mendekati $k^{*}$. Sepanjang transisi dari kondisi kapital rendah $\mathrm{k}$ (0) tingkat

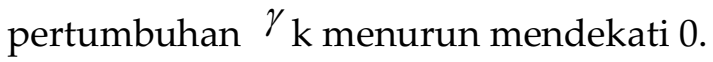

Untuk mengkaji hubungan kausalitas antara pengeluaran pemerintah dan pertumbuhan ekonomi, penelitian ini menggunakan teori pertumbuhan endogen (Endogenous Growth Theory). Teori pertumbuhan endogen memberikan penekanan pada pentingnya variabel modal manusia (human capital) dan variabel penelitian dan pengembangan (research and development $=R \mathcal{E} D$ ). Kedua variabel tersebut berkaitan erat dengan kebijakan pemerintah yang tercermin pada pengeluaran pemerintah dalam bidang infrastruktur, pendidikan dan kesehatan untuk pembentukan modal manusia dan kemajuan teknologi.

Penelitian ini menjadikan model pertumbuhan endogen dari Barro (1990) dan Barro, Sala-i-Martin (2004) sebagai grand theory karena memiliki relevansi dengan kondisi daerah-daerah di Indonesia pada umumnya dan Nusa Tenggara Barat khususnya.

\section{Teori New Growth (Endogenous Theory)}

Kajian 'endogenous' berawal dari Romer (1986), Lucas (1988), Robelo (1991) melakukan pengembangan dari studi sebelumnya yang dilakukan oleh Arrow (1962), Sheshinki (1967) dan Uzawa (1965) (Barro, Sala-i-Martin, 1995:12). Dalam model yang dikembangkan, pertumbuhan ekonomi dianggap berlangsung terus menerus tidak terbatas sebagai hasil dari investasi kapital termasuk human capital, sehingga hasil investasi ini tidak dengan sendirinya menurun ketika perekonomian berkembang (seperti dikemukakan oleh Knight [1944]). Selanjutnya adanya spillovers of knowledge diantara produsen dan manfaat eksternal kapital dalam bentuk sumber daya manusia merupakan bagian dari proses pertumbuhan. Kedua faktor tersebut dapat mengurangi kecenderungan diminishing returns sehingga akan terjadi akumulasi kapital.

Hal penting dalam model pertumbuhan yang dibangun oleh Romer (1990) adalah masuknya faktor R\&D yang berperan secara signifikan dalam pertumbuhan jangka panjang. Hal ini didukung pula oleh studi dari Grossman \& Helpman (1991) serta Aghion \& Howit (1992) (Barro, Sala-i-Martin, 2004: 12). Model-model tersebut menyatakan bahwa kemajuan teknologi merupakan hasil dari R\&D yang disertai dengan beberapa bentuk kekuatan monopoli. Bila dalam suatu perekonomian tidak terjadi kecenderungan penurunan ide, maka tingkat pertumbuhan jangka panjang akan tetap positif. Dalam kerangka ini, tingkat pertumbuhan jangka panjang dapat ditentukan oleh kebijakan pemerintah dalam aspek ekonomi.

Romer (1986), Robert Lucas (1988) mengembangkan tentang mekanisme pertumbuhan ekonomi yang bersifat endogen. Hasil pengamatan empirik kedua ekonom tersebut menunjukkan bahwa determinan pertumbuhan ekonomi jangka panjang memiliki banyak variabel yang sifatnya endogen. Pandangan atas variabel-variabel yang turut menentukan pertumbuhan ekonomi jangka panjang kemudian dimasukkan dalam model yang dibangun sehingga tidak lagi merupakan variabel yang eksogen. Romer (2001) menjelaskan mengenai teori endogen 
dengan memasukkan variabel $R \mathcal{E} D$ dan variabel Modal Manusia (human capital). Variabel $R$ \& $D$; dalam model tersebut dijelaskan bahwa kemajuan teknologi tergantung pada kuantitas modal dan tenaga kerja yang dipekerjakan dalam sektor R \& D dan tingkat teknologi. Dalam hubungan fungsional model tersebut dapat diformulasikan sebagai berikut :

$$
A(t)=G\left(a_{K} K(t), a_{L} L(t), A(t)\right)
$$

Dimana : A adalah merupakan tingkat produksi ide-ide baru.

Dalam bentuk fungsi produksi CobbDouglas persamaan tersebut dapat disusun kembali seperti berikut :

$$
A(t)=G\left[a_{K} K(t)\right]^{\beta}\left[a_{L} L(t)\right]^{\gamma}, A(t)^{\phi}
$$

$G$ adalah parameter, $G>0 \beta \geq 0, \gamma \geq 0$, Teori pertumbuhan endogen (endogenous growth theory) ini bebeda dengan model pertumbuhan ekonomi dari Neo-Klasik dalam hal asumsi-asumsi yang digunakan. Teori pertumbuhan Neo-klasik menyatakan bahwa dalam jangka panjang pertumbuhan ekonomi hanya mengandalkan faktor-faktor produksi saja dan tidak dapat dipertahankan secara terus menerus karena berlakunya low diminishing returnts to capital. Solow (1956) mengasumsikan bahwa kemajuan teknologi bersifat eksogen dimana ditentukan diluar faktor ekonomi, dan model Neo-klasik tidak memasukkan dampak eksternalitas ke dalam model. Padahal menurut New Growth teori eksternalitas dapat menciptakan increasing returns to scale.

Beberapa ciri yang membedakan model 'endogenous theory' dengan model pertumbuhan Neo-klasik adalah sebagai berikut (Ray, 1995: 63-76) :

1. Kemajuan teknologi yang bersifat endogen, yaitu sesuatu yang ditentukan oleh faktor-faktor ekonomi

2. Penekanan lebih banyak pada peran akumulasi modal.
3. Dimasukkannya dampak eksternalitas ke dalam model.

4. Implikasi model untuk kebijaksanaan yang bersifat intervensi.

Persamaan model Barro dan Sala-iMartin yang menyatakan bahwa tingkat pertumbuhan rata-rata diantara dua periode waktu, to dan $t_{0}+T$, adalah,

$\frac{1}{T} \cdot \log \left[\frac{y_{i, t 0}+T}{y_{i, t 0}}\right]=b-\left(\frac{1-e^{-\beta T}}{T}\right) \cdot \log \left(y_{i, t 0}\right)+u_{i, t 0, t 0+T}$

Selain model Barro dan Sala-i-Martin tersebut, memasuki abad ke-21, muncul gelombang baru dari penelitian pertumbuhan dengan model konvergensi yang membedakan antara konvergensi yang dihasilkan dari akumulasi modal dan konvergensi yang dihasilkan dari transfer teknologi, seperti Dowrick dan Rogers (2002).

\section{METODE PENELITIAN}

a. Jenis Penelitian

Penelitian ini merupakan jenis penelitian verifikatif yang bertujuan untuk mengkaji teori-teori ekonomi yang berhubungan dengan objek penelitian dengan menyusun hubungan antar variabel atas dasar formulasi rumusan dalam hipotesis. Dengan demikian penelitian ini akan melakukan hypothesis testing yaitu menganalisis hubungan antara satu variabel (dependent variable) dengan sejumlah variabel lain (independent vabiable) melalui pengujian hipotesis dari serangkaian data empiris yang telah dipublikasikan (ex-post facto).

b. Daerah/Lokasi Penelitian

Penelitian ini dilakukan di seluruh daerah kabupaten/kota provinsi Nusa Tenggara Barat, dengan pertimbangan bahwa tingkat pertumbuhan dan perioritas kebijakan pembangunan di masingmasing daerah kabupaten/kota memiliki karakteristik yang berbeda-beda (heterogen) 
c. Metode Pengumpulan Data

Proses pengumpulan data dilakukan dengan menyusun matrik variabelvariabel yang diperlukan sesuai dengan model analisis. Pengumpulan data dilakukan dari berbagai sumber untuk dapat saling melengkapi kekurangan satu dengan lainnya. Untuk menjamin tingkat akurasi data yang dipergunakan dilakukan deflator dan penyesuaian terhadap sejumlah data. Hal ini dilakukan mengingat data yang digunakan berasal dari berbagai sumber dan kemungkinan menggunakan tahun dasar yang berbeda dalam perhitungannya.

d. Teknik Pengumpulan Data

Teknik pengumpulan data dalam penelitian dilakukan dengan dokumentasi dan studi kepustakaan.

e. Jenis dan Sumber Data

Data yang digunakan dalam penelitian ini adalah data sekunder berupa data time series periode 2000 - 2015 dan data crosssection antar kabupaten/kota di provinsi Nusa Tenggara Barat. Data yang diperlukan meliputi : data PDRB seluruh kabupaten/kota berdasarkan harga konstan, pengeluaran pemerintah daerah (APBD), pendapatan per kapita, dan data tingkat pertumbuhan ekonomi.

Sumber data yang akan digunakan diharapkan dapat terpenuhi dari beberapa publikasi resmi dan website lembaga atau badan milik pemerintah seperti :

- Badan Pusat Statistik (BPS)

- Departemen Keuangan

- Bank Indonesia

- Pemerintah

Daerah kabupaten/kota di Nusa Tenggara Barat

f. Prosedur Analisis

Metode analisis yang digunakan adalah analisis kuantitatif dengan metode regresi data panel (pooled data) yaitu kombinasi data time series dan data cross-section (Gujarati: 2003, Pindyk dan Rubinfeld: 1998).
Dalam penelitian ini pendugaan persamaan dilakukan dengan pendekatan ekonometrika data panel, dan dengan mempertimbangkan asumsi yang digunakan mengenai intersep, slope, dan sisaan $\mathrm{u}_{\mathrm{it}}$, sehingga berdasarkan variasivariasi asumsi yang dibentuk akan diuji tiga model regresi data panel tersebut, yaitu: (1) Metode Common Effect Model (CEM) atau dikenal juga dengan sebutan Metode Pooled Least Square (PLS); (2) Metode Fixed Effect Model (FEM); dan (3) Metode Random Effect (REM).

Spesifikasi model yang digunakan untuk pengujian hipotesis konvergensi ( $\beta$ dan $\sigma$ ) digunakan persamaan dari Barro dan Salai-Martin (2004) sebagai berikut :

$\left(\frac{1}{T}\right) \log \left[\frac{y_{i T}}{y_{i 0}}\right]=\alpha-\frac{\left(1-e^{-\beta T}\right)}{T} \cdot \log y_{i 0}+X_{i, 1}+u_{i 0, T}$

Dimana $X$ adalah vekor dari variabelvariabel yang mempengaruhi steady-state perekonomian i. Kecepatan konvergensi atau speed of convergence menunjukkan kecepatan suatu daerah untuk mencapai titik steady state. Dalam penelitian ini di sebut kecepatan konvergensi, dihitung menggunakan formula dari koefisien pada pendapatan awal :

$$
\boldsymbol{\beta}=\frac{\left(1-e^{-\beta T}\right)}{T}
$$

Dimana $\mathrm{T}$ adalah panjangnya periode observasi (Wibisono, 2005).

Definisi Variabel \& Sumber Data (Model Barro \& Sala-i-Martin : 2004)

\begin{tabular}{|l|l|l|}
\hline \hline \multicolumn{1}{|c|}{ Variabel } & \multicolumn{1}{|c|}{ Definisi } & \multicolumn{1}{|c|}{ Sumber Data } \\
\hline \hline $\begin{array}{l}\text { Tingkat Pertumbuhan } \\
\text { (variabel dependen) }\end{array}$ & $\begin{array}{l}\text { Tingkat pertumbuhan tahunan } \\
\text { dari PDRB perkapita riil 2010- } \\
2015\end{array}$ & $\begin{array}{l}\text { BPS. Produk Domestik } \\
\text { Regional Bruto Provinsi } \\
\text { NTB }\end{array}$ \\
\hline Pendapatan Awal & $\begin{array}{l}\text { Logaritma natural dari PDRB per } \\
\text { kapita riil pada tahun dasar } \\
\text { penelitian }\end{array}$ & $\begin{array}{l}\text { BPS. Produk Domestik } \\
\text { Regional Bruto Provinsi } \\
\text { NTB }\end{array}$ \\
\hline $\begin{array}{l}\text { Belanja Pemerintah } \\
\text { (belanja modal) }\end{array}$ & $\begin{array}{l}\text { Pertumbuhan/ratio belanja modal } \\
\text { pemerintah daerah terhadap } \\
\text { PDRB }\end{array}$ & $\begin{array}{l}\text { Kemenkeu. Dirjen } \\
\text { Perimbangan Keuangan } \\
\text { Pusat dan Daerah }\end{array}$ \\
\hline
\end{tabular}

\section{HASIL PENELITIAN DAN PEMBAHASAN}




\section{Pertumbuhan Ekonomi Daerah}

Dinamika perekonomian suatu daerah dapat dilihat dari tingkat Produk Domestik Regional Bruto (PDRB) dalam suatu periode tertentu. Pertumbuhan ekonomi antar kabupaten/kota di Nusa Tenggara Barat sangat bervariasi, selain dipengaruhi oleh ketersediaan sumberdaya alam (faktor endowment) juga dipengaruhi oleh ketersediaan infrastruktur di daerah dan kebijakan pemerintah. Daerah-daerah yang memiliki infrastruktur relatif lebih baik dibandingkan dengan daerah lain akan cenderung memiliki tingkat pertumbuhan ekonomi yang lebih tinggi. Pertumbuhan ekonomi berhubungan erat dengan proses transformasi sebagai hasil pembangunan nasional ataupun regional.

Pertumbuhan ekonomi sangat mempengaruhi penciptaan lapangan kerja terutama sektor-sektor ekonomi yang mempunyai elastisitas kesempatan kerja yang tinggi. Pertumbuhan ekonomi daerah yang didorong oleh peningkatan investasi akan meningkatkan penyerapan tenaga kerja. Pertumbuhan ekonomi dalam beberapa tahun terakhir ini cenderung didorong oleh peningkatan konsumsi sehingga walaupun terjadi pertumbuhan ekonomi namun sangat lambat dalam penciptaan lapangan kerja.

Gambar : 4.1.

Pertumbuhan Ekonomi Kab/Kota di Nusa Tenggara Barat tahun 2010-2015.

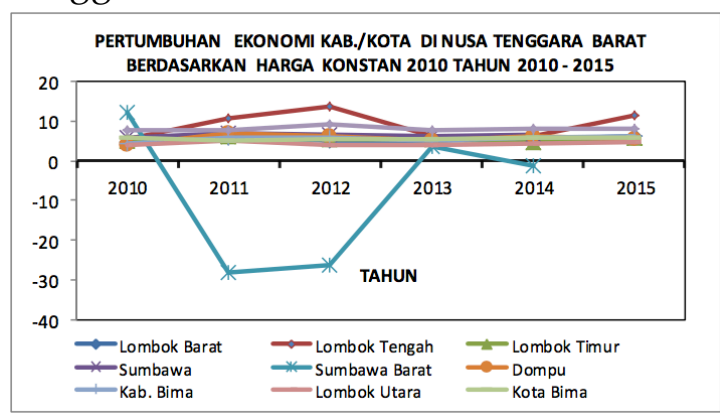

Sumber : Data BPS diolah.
Selama periode pengamatan 2010-2015 pertumbuhan ekonomi daerah mengalami fluktuasi. Beberapa daerah mengalami pertumbuhan ekonomi melebihi rata-rata pertumbuhan ekonomi provinsi dan terdapat sejumlah daerah tumbuh dibawah rata-rata provinsi.

Gambar : 4.2., Scater Plot Rata-rata Pertumbuhan Ekonomi Kabuapen/Kota dan Pertumbuhan Ekonomi Provinsi Nusa Tenggara Barat

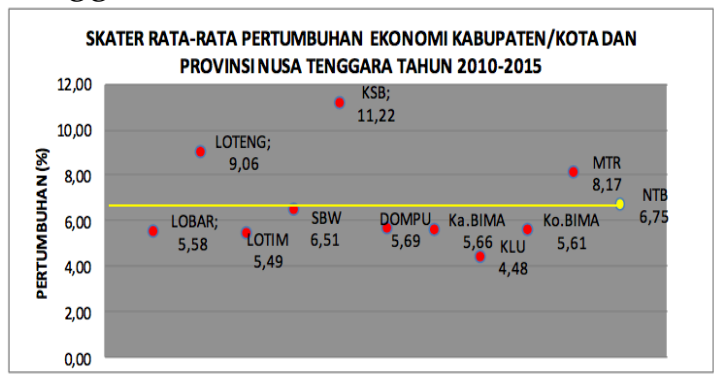

Rata-rata pertumbuhan ekonomi provinsi selama periode 2010-2015 mencapai 6,75\%. Pertumbuhan ekonomi tertinggi dicapai kabupaten Sumbawa Barat mencapai 11,22 $\%$, sedangkan pertumbuhan ekonomi terendah terjadi di kabupaten Lombok Utara hanya sebesar $4,48 \% \%$. Beberapa daerah mengalami pertumbuhan ekonomi di atas rata-rata pertumbuhan ekonomi provinsi yaitu : Kota Mataram mencapai 8,17\%, Kabupaten Lombok Tengah sebesar 9,06 \% dan Kabupaten Sumbawa Barat sebesar 11,22.

\section{Pengeluaran Pemerintah Daerah} Dalam struktur Anggaran Pendapatan dan Belanja Daerah (APBD) setelah Undang-Undang Otonomi Daerah secara garis besar pola pengeluaran pemerintah daerah dikelompokkan menjadi belanja langsung dan belanja tidak langsung. Belanja langsung mempunyai peranan dan fungsi yang cukup penting di dalam mendukung pencapaian sasaran pembangunan walaupun pengeluaran tersebut tidak secara langsung berkaitan dengan kegiatan pembentukan modal 
untuk tujuan peningkatan produksi, namun strategi dan arah kebijaksanaan pengeluaran rutin berpengaruh luas di dalam menunjang tercapainya sasaran pembangunan melalui peranannya mendukung kelancaran kegiatan operasional pemerintahan dalam memberikan pelayanan kepada masyarakat. Selama periode analisis, jumlah dan peranan belanja ini mengalami peningkatan sejalan dengan perkembangan organisasi, tugas dan fungsi pemerintah dalam rangka melaksanakan tugas-tugas umum pemerintahan yang semakin meningkat dan meluas. Peningkatan tersebut erat kaitannya dengan semakin besarnya kebutuhan pembiayaan yang diperlukan bagi pendayagunaan aparatur pemerintah daerah.

Pengeluaran pembangunan (belanja modal) lebih diarahkan untuk menggerakkan ativitas perekonomian dan memacu pertumbuhan ekonomi melalui serangkaian kebijakan strategis. Anggaran belanja modal mempunyai peranan yang sangat penting dalam mencapai sasaran pokok pembangunan yang direncanakan dan telah ditetapkan pemerintah. Sebagai piranti kebijaksanaan fiskal, anggaran belanja modal di dalam APBD mempunyai pengaruh yang cukup kuat di dalam menentukan, arah dan pola alokasi sumber daya ekonomi antar bidang, antar sektor, dan antar kegiatan dalam masyarakat, maupun distribusi hasil pembangunan. Demikian pula dari segi jumlah maupun strategi pengalokasiannya antar daerah dan antar sektor, belanja modal mempunyai pengaruh terhadap arah perkembangan ekonomi di berbagai bidang, baik produksi dan kesempatan kerja, maupun distribusi pendapatan dan pemerataan pembangunan. Sejalan dengan semakin meluasnya program pembangunan yang dilaksanakan pemerintah, anggaran pembangunan senantiasa menunjukkan peningkatan dari tahun ke tahun. Pertumbuhan jumlah belanja modal pemerintah daerah kabupaten/kota di provinsi Nusa Tenggara Barat seperti terlihat pada diagram berikut ini.

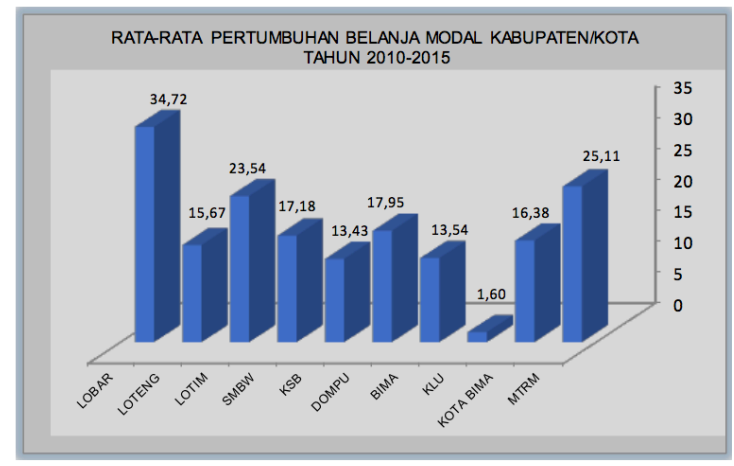

Anggaran belanja modal pemerintah diarahkan untuk memenuhi dua kebutuhan. Pertama, sesuai dengan semangat otonomi daerah, belanja pembangunan yang dikelola pemerintah digunakan untuk membiayai pelaksanaan tugas yang menjadi tanggung jawab dan wewenang pemerintaht. Kedua, anggaran pembangunan yang dikelola oleh pemerintah juga digunakan untuk pemerataan pembangunan antar daerah melalui pelaksanaan dekonsentrasi dan tugas pembantuan, khususnya dalam penyediaan pelayanan kebutuhan dasar masyarakat. Anggaran belanja modal diarahkan pemanfaatannya berdasarkan prioritas pada proyek-proyek yang produktif, dalam arti menghasilkan nilai produksi yang lebih besar dan mempunyai multiflier efect yang tinggi. Dalam hal pelaksanaan fungsi alokasi pemerintah, penentuan skala prioritas senantiasa didasarkan pada strategi pembangunan yang menitik beratkan pada pembangunan sektor-sektor ekonomi. Dengan kerangka acuan tersebut, prioritas belanja pembangunan diberikan kepada penyediaan prasarana dasar yang dapat mendorong berkembangnya kegiatan ekonomi masyarakat, baik secara langsung 
maupun tidak langsung. Dengan tersedianya prasarana dasar tersebut diharapkan kegiatan perekonomian, seperti perdagangan, penanaman modal, dan kegiatan ekonomi lainnya menjadi lebih meningkat, sehingga mampu menunjang penciptaan kesempatan kerja dan meningkatkan pertumbuhan ekonomi. Selanjutnya dalam rangka pelaksanaan fungsi distribusi, alokasi anggaran pembangunan diarahkan antara lain kepada berbagai program bantuan pembangunan daerah untuk mengurangi ketimpangan regional.

\section{Analisis Arah dan Percepatan Pembangunan Daerah}

Solow Swan Model menjelaskan bahwa tingkat pertumbuhan ekonomi suatu negara atau daerah akan bertemu pada satu titik (terjadinya catching up effect). Pada waktunya negara atau daerah berkembang akan berhasil mengejar negara atau daerah yang sudah maju dengan asumsi negara atau daerah yang maju masuk dalam kondisi yang steady state. Salah satu prediksi dari teori pertumbuhan Solow Swan adalah dikemukakannya hipotesis konvergensi yang menyatakan bahwa akan terjadi catching up effect.

Penelitian ini mencoba men-generate alur pikir konvergensi ini ke dalam tataran pembangunan ekonomi didaerah kabupaten/kota provinsi Nusa Tenggara Barat, apakah pertumbuhan ekonomi kabupaten/kota akan cenderung menuju tendensi yang bersifat konvergen ataukah divergen selama periode 2010 - 2015 . Penelitian ini melakukan simulasi pembuktian hipotesis konvergensi data time series periode 2010 - 2015. Mengikuti Model Barro dan Sala-i-Martin (2004) identifikasi terjadinya konvergensi dibagi menjadi konvergensi bruto (absolute convergence) dan konvergensi beta (conditional convergence).
Tabel 4.1. Estimasi absolut convergence (absolute convergence) Kabupaten/Kota di Provinsi Nusa Tenggara Barat Tahun 2010 $-2014$

\begin{tabular}{|l|l|c|c|c|}
\hline \hline \multirow{2}{*}{ Variabel Independen } & \multicolumn{2}{c|}{ Common Effect } & \multicolumn{2}{c|}{ Fixed Effect } \\
\cline { 2 - 5 } & \multicolumn{1}{|c|}{ Coef. } & p-value & Coef. & p-value \\
\hline \hline Konstanta & 0.28388 & 0.0115 & 0,6259 & 0,0000 \\
\hline Log (PDRB perkapita 2010) & $-0,2471$ & 0.0144 & $-0,1370$ & 0,0540 \\
\hline $\mathbf{R}^{\mathbf{2}}$ & 0.19562 & & 0,6873 & \\
\hline $\mathbf{R}^{2}$ adjust & 0.16689 & & 0,5795 & \\
\hline F-Statistic & 6.80959 & & 6,3747 & \\
\hline Prob. (F-Stat) & 0.01439 & & 0,0000 & \\
\hline & & & & \\
\hline Speed of Convergence, \% & 3,7 & & 2,1 & \\
\hline Half-life & 19 & & 32 & \\
\hline
\end{tabular}

Sumber: Hasil Pengolahan Data

Tabel di atas menunjukkan bahwa berdasarkan hasil pendugaan model common effect (CEM), model fixed effect (FEM), terjadi tendensi konvergensi absolut pendapatan perkapita antar Kabupaten/Kota di Provinsi NTB selama periode 2010-2015. Hal ini ditunjukkan oleh nilai koefisien parameter pendapatan per kapita awal $(\beta)$ yang memiliki arah (sign) negatif yang menunjukkan tanda yang sesuai harapan atau konsisten dengan teori dan dengan kecepatan konvergensi absolut berkisar antara 2,14\% hingga $3,710 \%$ per tahun serta half-life antara selama 19 - 32 tahun.

Tabel 4.2. Estimasi Tendensi Conditional Convergence Kabupaten/Kota di Provinsi Nusa Tenggara Barat Tahun 2010-2014

\begin{tabular}{|l|l|l|l|l|}
\hline \hline \multirow{2}{*}{ Variabel Independen } & \multicolumn{2}{|c|}{ Common Effect } & \multicolumn{2}{c|}{ Fixed Effect } \\
\cline { 2 - 5 } & Coef. & p-value & Coef. & p-value \\
\hline \hline Konstanta & 0.08900 & 0.7686 & 0.50610 & 0.0000 \\
\hline $\begin{array}{l}\text { Log (PDRB perkapita } \\
\text { 2010) }\end{array}$ & -0.16052 & 0.67719 & -0.2436 & 0.0000 \\
\hline Belanja Modal & & & & \\
\hline $\mathrm{R}^{2}$ & 0.0024 & 0.7880 & 0.01208 & 0.0014 \\
\hline $\mathrm{R}^{2}$ adjust & 0.1476 & & 0.9085 & \\
\hline F-Statistic & 0.0691 & & 0.8223 & \\
\hline Prob. (F-Stat) & 0.8357 & & 12.1487 & \\
\hline & 0.5425 & & 0.0000 & \\
\hline Speed of Convergence, \% & 0,98 & & & \\
\hline Half-life & 28 & & 19 & \\
\hline
\end{tabular}

Sumber: Hasil Pengolahan Data

Hasil pengujian terhadap tendensi konvergensi kondisional (conditional convergencet) dengan Common Effect Model (CEM) dan Fixct Effect Model (FEM) menunjukkan koefisien pendapatan 
per kapita awal (initial PDRB per capita) negatip. Dengan demikian dapat dinyatakan bahwa proses pembangunan ekonomi di Nusa Tenggara Barat bertendensi konvergen. Pendugaan proses konvergensi menunjukkan kecepatan yang berbeda-beda, masing-masing sebesar 0,98\% per tahun, 3,63\% per tahun dan bermuara pada perbedaan percepatan pencapaian half-life, masing-masing selama 28 tahun, dan 19 tahun.

\section{KESIMPULAN DAN SARAN}

\subsection{Kesimpulan}

Hasil penelitian melalui estimasi model dan pengujian hipotesis maka dapat dirumuskan beberapa kesimpulan sebagai berikut :

1. Terjadi tendensi konvergensi pertumbuhan ekonomi antar kabupaten/kota di Provinsi NTB selama periode pengamatan. Hal ini ditunjukkan dengan koefisien konvergensi yang bernilai negatif pada absolut convergence maupun conditional convergence.

2. Penggunakan model konvergensi, yaitu konvergensi klasik dengan model Barro dan Sala-i-Martin didapatkan kecepatan konvergensi yang berbeda-beda.

3. Berdasarkan model konvergensi yang digunakan pada penelitian ini, terlihat jelas bahwa peranan pemerintah melalui kebijakan publik memiliki pengaruh yang cukup besar dalam mendorong pertumbuhan ekonomi. Hal ini ditunjukkan oleh variabel belanja pemerintah yang mempunyai pengaruh positif dan signifikan dalam mendorong percepatan konvergensi maupun pendorong pertumbuhan ekonomi.
Beberapa saran atau rekomendasi kebijakan yang diajukan berdasarkan pada hasil penelitian yang diuraikan sebelumnya sebagai berikut :

1. Bentuk keberpihakan pemerintah kepada publik adalah peningkatan belanja modal, oleh karena itu, kedepan pemerintah dapat lebih memperhatikan kebijakan anggaran yang berpihak pada pembangunan untuk penyediaan fasilitas publik yang mendorong pertumbuhan ekonomi masyarakat.

2. Selain pemerintah daerah nampaknya pemerintah pusat melalui kebijakan anggaran (APBN) harus terlibat dan memperhatikan daerah untuk mendorong pertumbuhan ekonomi daerah kabupaten/kota di Provinsi Nusa Tenggara Barat.

\section{DAFTAR PUSTAKA}

Agustino Landiyanto, Erlangga. 2007. "Growth and Convergence of Sugarcare Industries in Southeast Asia". Munich: Munich Personal RePEc Archive

Arikunto, Suharsimi. 2002. Prosedur Penelitian: Suatu Pendekatan Praktek. Jakarta: Penerbit: PT. Rineka Cipta

Arsyad, Lincolin. 1999. Pengantar Perencanaan dan Pembangunan Ekonomi Daerah. (1st ed.). Yogyakarta: BPFE-UGM.

Barro, Robert J \& Xavier Sala-iMartin. 1992. "Convergence." The Journal of Political Economy, Vol. 100, Apr., pp. 223-251 
Growth". New York: McGraw-Hill.

Barro, Robert J. 1998. "Human Capital and Growth in Cross Country Regressions". Journal of Economics, Jurnal of Economics Harvard University No. 214.

Bryson, John M, 2007, Perencanaan Strategis bagi Organisasi Publik dan Sosial, Pustaka Pelajar, Yogyakarta.

Glasson J, 1977, Pengantar Perencanaan Regional Terjemahan dari $A n$ Introduction to Regional Planning . Penerjemah Sitohang P. Jakarta Lembaga Penerbit Fakultas Ekonomi Universitas Indonesia.

Kementerian Dalam Negeri Republik Indonesia. 2009. Konsepsi dan Teori Pengembangan Wilayah: Author

Kuncoro, Haryo. 2008. "Konvergensi Pendapatan Regional Kota dan Kabupaten di Indonesia." Jurnal Eko-Regional, Vol 3 No 1, Maret 2008

Kuncoro, Mudrajad. 2004. “Otonomi dan Perkembangan Daerah: Reformasi, Perencanaa, Strategi, dan Peluang". Jakarta: Erlangga.

2002. "Analisis Spasial dan Regional: Studi Aglomerasi dan Kluster Industri Indonesia". Yogyakarta: UPP-AMP YKPN.

Mankiw, Gregory. 2007. "Makroekonomi”. Jakarta: Penerbit Erlangga.

Mardikanto, Totok,

Prof,.Dr,.Ir,.MS,2010,Tahapan

Perencanaaan Program/kegiatan

Pemberdayaan Masyarakat.
Nazir, Mohammad. 2005. “Metode Penelitian". Jakarta: Ghalia Indonesia.

Rustiadi E, Saefulhakim S dan Panuju RD. 2009, Perencanaan dan Pengembangan Wilayah, Jakarta. Crestpten Press dan Yayasan Obor Indonesia.

Sala-i-Martin, X. 1996. "The Classical Approach to Convergence Analysis". The Journal of Political Economy. Vol. 106. P. 1019-1036

Sjafrizal. 1997. "Pertumbuhan Ekonomi dan Ketimpangan Regional Wilayah Indonesia Bagian Barat". Prisma LP3ES.

Sugiyono, 2010, Metode Penelitian kuantitatif Kualitatif dan R\&D , Penerbit Alfabeta, Bandung.

Todaro, Michael P. \& Stephen C. Smith. (2006). “Ekonomi Pembangunan Jilid 9". Jakarta: Penerbit Erlangga.

Wahyunadi. 2007. “Pengaruh Sektor Pemerintah terhadap Konvergensi Pertumbuhan Ekonomi NTB Periode 1980-2000". Jurnal Penelitian Unram, Vol 2 No 9, Februari 2007

Waluyo, Joko. 2007. "Dampak Desentralisasi Fiskal terhadap Pertumbuhan Ekonomi dan Ketimpangan Pendapatan antardaerah di Indonesia". Artikel yang disampaikan pada Paralel Discussion yang dilakukan oleh Universitas Indoensia di Wisma Makara-Kampus UI, Depok

Wibisono, Yusuf. 2005. "Sumber-sumber Pertumbuhan Ekonomi Regional". Jurnal Ekonomi dan Pembangunan Indonesia, vol 5 no 02 